\title{
ОЦІНКА ВЗАЕМОЗВ'ЯЗКУ ПАРАМЕТРІВ СТАЛОГО РОЗВИТКУ РЕГІОНІВ УКРАЇНИ
}

\begin{abstract}
В статті проведено корелячійний аналіз параметрів сталого розвитку регіонів. Були сформовані системи параметрів в економічній, соціальній та екологічній сферах. Вихідними параметрами було обрано загрози, запропоновані в дослідженні Світового Центру даних з геоінформатики та сталого розвитку «Аналіз сталого розвитку: глобальний $і$ регіональний контексти». Вхідні параметри було визначено на основі кореляційного аналізу статистичних даних. Авторами визначено основну низку проблем, пов'язаних із оцінкою сталого розвитку в регіонах та окреслено перспективи подальших наукових досліджень в иььому напрямку.
\end{abstract}

Ключові слова: сталість, сталий розвиток, параметри сталого розвитку, кореляиійний аналіз, Державна служба статистики.

Постановка проблеми. Успіх впровадження сталого розвитку залежить від метрики. Наразі вже створено стратегії на міському та регіональному рівнях. Відбувається постійний пошук більш актуальних параметрів та аналіз зв'язку між ними. Система параметрів має відображати стан об'єкту дослідження за комплексом показників, які характеризують ту чи іншу сферу діяльності за певний період часу.

Тому можна виділити головну проблему який комплекс параметрів сталого розвитку $\epsilon$ найбільш ефективним для моделювання з метою оцінки сталості регіонів та міст. Усі нижчезгадані дослідження направленні на вирішення цього питання.

Як об'єкт дослідження держава - складна система. Але регіон чи місто - теж складні та слабоструктуровані системи. Тому існує об'єктивна потреба в оцінці ступеня нестабільності середовища, а також у виробленні підходів до його аналізу. В цьому аспекті вибір оптимального добору параметрів, за якими буде визначатись відповідність цілям сталості, $\epsilon$ одним із першочергових та актуальних питань. 3 цього приводу основною задачею $\epsilon$ аналіз існуючих систем параметрів та визначення проблем, пов'язаних з їх застосуванням.

Аналіз останніх досліджень і публікацій. Варто згадати ключові події які описати шлях розвитку людства сьогодні:

$\checkmark$ перша глобальна конференція в Стокгольмі в 1972 році та публікація «The Limits to Growth»;

(C) Чуріканова Олена Юріївна, к.е.н., доцент кафедри електронної економіки та економічної кібернетики, Державний ВНЗ «Національний гірничий університет»

Загорулько Костянтин Андрійович, аспірант кафедри електронної економіки та економічної кібернетики, Державний ВНЗ «Національний гірничий університет» $\checkmark$ наступна світова зустріч в Ріо в 1992 році, де було прийнято 3 основні договори;

$\checkmark$ наслідком проведення Саміту тисячоліття ООН в 2000 році було прийняття «Цілей розвитку тисячоліття〉 (ЦРТ);

$\checkmark$ остання подія була у 2015, яка закінчилась прийняттям «Цілей сталого розвитку».

Вперше запропоновано систему факторів i розроблено метрику для вимірювання процесів сталого розвитку регіонів України у першому збірнику Світового Центру даних 3 геоінформатики та сталого розвитку (далі СЦД) [1] при КПІ «Аналіз сталого розвитку: глобальний і регіональний контексти» у 2009 році. В останньому збірнику «Україна в індикаторах сталого розвитку 2013» [2] вони пропонують методичний підхід до аналізу $\mathrm{CP}$, який ввібрав в себе досвід попередників, роботи експертів 3 трьох сфер: економічної, екологічної та соціальної.

Внаслідок динамічних тенденцій в усіх сферах нашої держави потрібно й надалі досліджувати зв'язки в середині кожної сфери та цих трьох сферах разом. Також вказана причина ускладнює роботу експертів, а іноді навіть робить неможливим моделювання системи.

Саме через неможливість оцінювати як той чи інший параметр впливає на систему, невирішеним питанням залишається розробка автоматичної системи як допоміжний засіб у роботі експертів та полісімейкерів. Через існування безлічі параметрів сталого розвиту, експертам треба щорічно визначати групи найбільш вагомих параметрі. Тому розробка автоматичної системи дозволить експертами більше часу приділити інтерпретації кінцевих результатів.

Формулювання цілей статті. Наразі мета авторського дослідження - це аналіз взаємозв'язку параметрів сталого розвитку регіонів та визначення вихідних і вихідних параметрів. 
Опис основного матеріалу дослідження. Зібравши дані 3 Держаної служби статистики України, профільних міністерств та неурядових організацій, СЦД створили потужну базу даних 3 вільним доступом [1], яка була використана в цьому дослідженні. В аналізі були використані дані з СЦД, а саме показники 145 параметрів 323 регіонів в період від 2004 до 2014 року, тобто маємо 253 спостереження.

Крім запропонованих відповідними фахівцями параметрів, індикаторів та категорій політик [2, стр. 9-32] були ще запропоновані загрози [2, стр. 9-36 ], що підривають сталість регіонів. Ці загрози були розраховані за запропонованими експертами методиками, які були опублікуванні у вищезгаданому збірнику СЦД. Відповідні загрози буде дуже доречно використати як цільові функції або вихідні параметри для аналізу та розробки політики у сфері сталого розвитку.

Сформувавши масив вихідних параметрів треба сформувати масив вхідних параметрів. Для цього всі можливі вхідні параметри шляхом кореляційного аналізу треба відсортувати та залишити тільки значимі. Таким чином, для подальших досліджень залишаться тільки ті параметри, які мають вплив на вихідні параметри, тобто показники сталого розвитку регіонів. В результаті цього аналізу буде сформована нова система вхідних та вихідних параметрів.

Проаналізувавши дослідження СЦД [2] та інших вітчизняних вчених $[3,4,5,6,7,8]$, встановлено ряд факторів, які відображають результативність сталого розвитку регіонів. На нашу думку, найбільш доречним буде використання групи економічних, екологічних, та соціальних факторів, а також загроз, представлених у роботі «Україна в індикаторах сталого розвитку 2013» [2].

А отже в рамках цього дослідження, як вихідні параметри сталого розвитку встановлено:

Економічна сфера: «Показник розвитку економіки» (кількісно характеризується параметром VRP); «Рівень безробіття» (BN); «Технологічна відсталість» (RZOF); «Зниження добробуту населення» (DNO).

Соціальна: «Зниження тривалості життя» (кількісно характеризується параметром LIFE_EXP); «Злочинність» (CRIME); «Корупція» (CORR_PER); «Соціальна нерівність» (CIR); «Погіршення здоров'я» (MORT).

Екологічна: «Дефіцит водних ресурсів» (параметр забезпеченості місцевими водними ресурсами WRS); «Вплив на змінювання клімату» (показник щільності викидів двоокису карбону ССH).

\section{Аналіз економічної сфери}

Для аналізу сили лінійної залежності між параметрами було взято коефіцієнт кореляції Пірсона.

Далі треба проаналізувати самі коефіцієнти кореляції, враховуючи стандартну шкалу інтерпретації ( якщо значення $0.3-0.5$, тоді мала залежність; $0.5-0.7$, тоді середня; $0.7-0.9$ це висока; 0.9 - 1 дуже висока).

3 огляду на те, що причинно-наслідкові зв'язки неявні, було прийнято рішення залишити параметри, які мають коефіцієнт кореляції щонайменше 0.4 , додатково обрахувавши для них рівень значимості коефіцієнтів кореляції.

У цій сфері ми маємо вхідні та вихідні параметрів у кількості 42.

У таблиці 1 представлені результати кореляційного аналізу.

Цікаво, що показник «Валовий регіональний продукт у розрахунку на одну особу» (GRP) має слабкий зв'язок з усіма параметрами.

У своїй методології СЦД використовують VRP як узагальнюючий показник розвитку економіки регіонів [2, стр.32].

Параметр «Частка населення із середньомушовими еквівалентними грошовими доходами на місяць нижче прожиткового мінімуму» (ILLW) сильно корелює лише 3 параметром «Частка витрат на продукти харчування та безалкогольні напої у середньому за місяць у розрахунку на одне домогосподарство» (FNADAM). Обидва ці параметри можуть розцінюватися як показники економічного благополуччя, але останній має більш сильний зв'язок $з$ параметрами «Наявний доход у розрахунку на одну особу» (DNO), «Baловий регіональний продукт» (VRP), «Середньомісячна заробітна плата» (SMZP). Також ILLW має незначний лінійний зв'язок з VRP.

Дуже сильна кореляція у параметрів «Наявний доход у розрахунку на одну особу» (DNO) та «Середньомісячна заробітна плата» (SMZP). Раціональним рішенням буде прибрати SMZP через те, що DNO є одним 3 обраних вихідних параметрів.

У статті Карен Даннелл [9] аргументовано чому альтернативою VRP як показника економічного результату регіону $\epsilon$ «Валова додана вартість» та «Валовий дохід домогосподарства». Виконуючи аналіз параметрів розроблених СЦД [1,2] є лише один показник, який можна використовувати як альтернативу - це «Валовий дохід на домогосподарство» (DNO). 


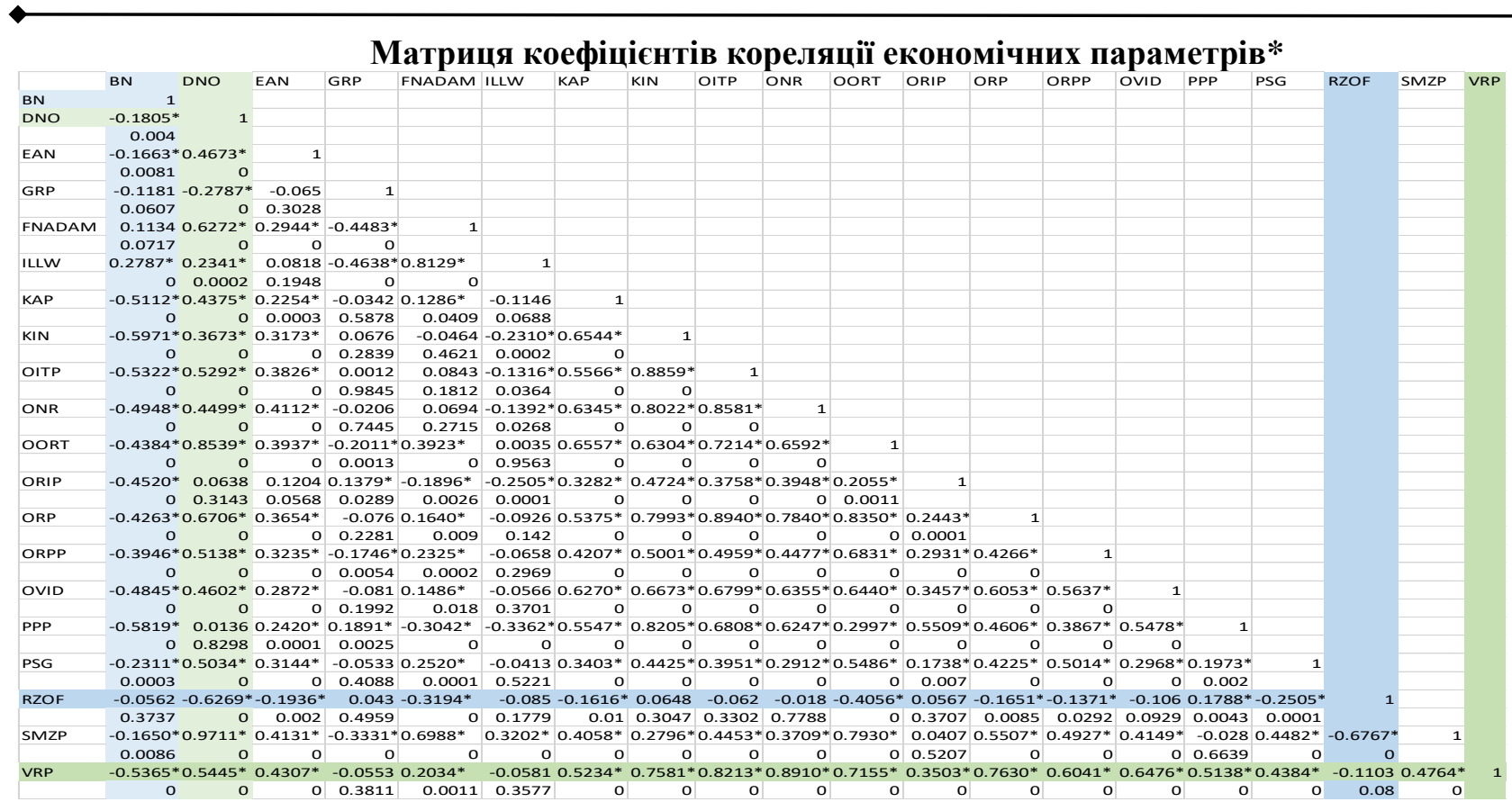

* Розроблено автором

Дуже сильно корелює VRP 3 «Обсяг наукових та науково-технічних робіт, виконаних власними силами наукових організацій» (ONR). Але ці показники по суті не дублюють один одного.

Через вище згадані причини були прибрані 3 аналізу параметри ILLW, GRP та SMZP.

Для більш детального опису економічного становища необхідно додатково провести кореляційний аналіз за більшою вибіркою параметрів. Але це не гарантує суттєво кращий результат через те, що система, розроблена СЦД,

включає в себе всі значущі параметри за думкою експертів. Але завдяки титанічній праці по збору та обробки даних, зробленою СЦД, ми маємо достатньо спостережень для побудови лінійної регресійної моделі, аби остання була адекватною відповідно до Van Voorhis \& Morgan (2007) [10].

\section{Аналіз соціальної сфери}

У цій сфері ми маємо вхідні та вихідні параметри разом у кількості 42. Аналіз буде складатися 3 трьох частин та результатом будуть створені три таблиці.

Таблиця 2

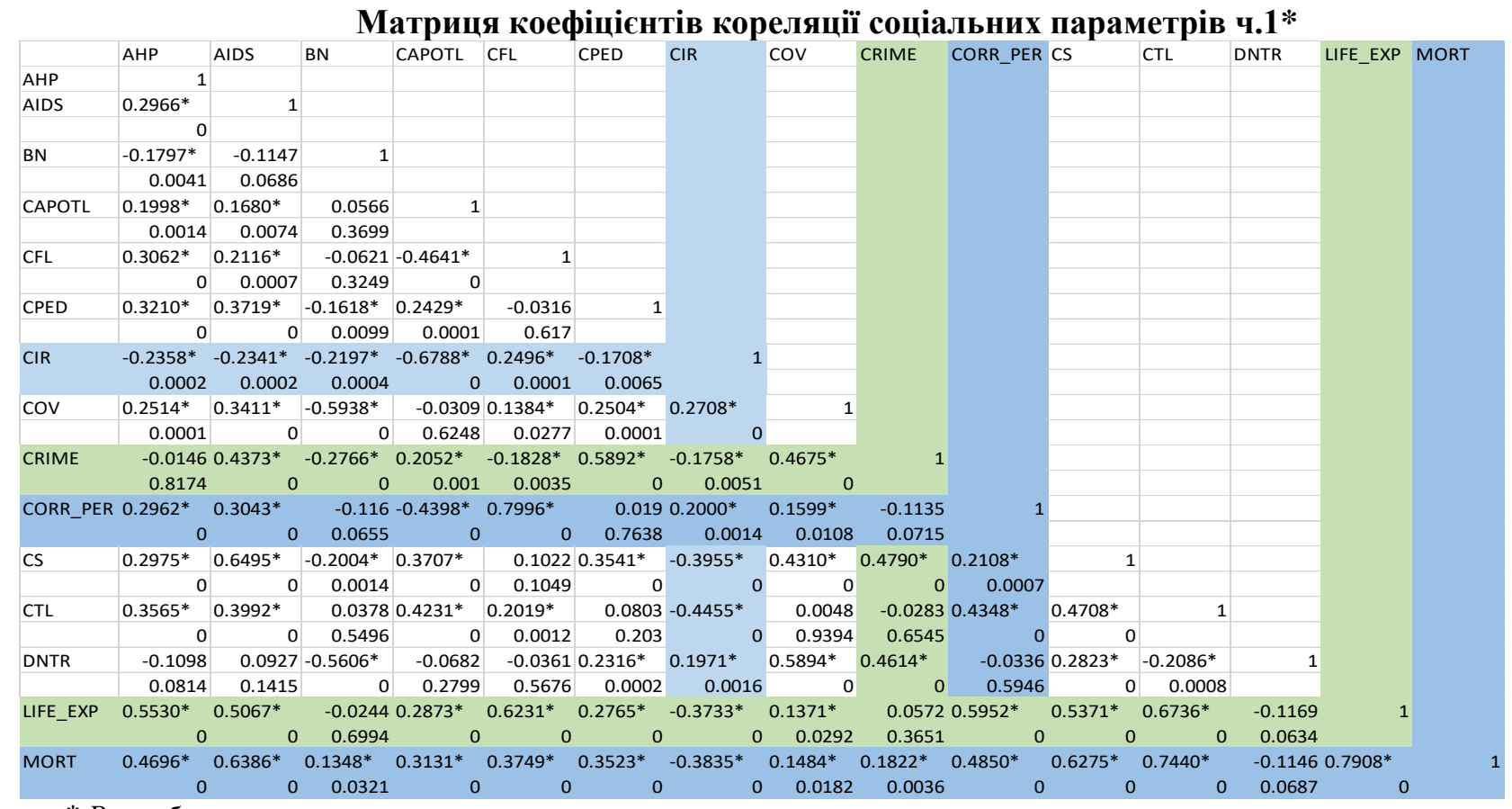

* Розроблено автором

Проаналізувавши коефіціснти наведенні в таблиці 2, параметри BN, DNTR мають слабкий

рівень зв'язку з вихідними параметрами, тому їх треба виключити з аналізу. 
Таблиця 3

Матриця коефіцієнтів кореляції соціальних параметрів ч.2*

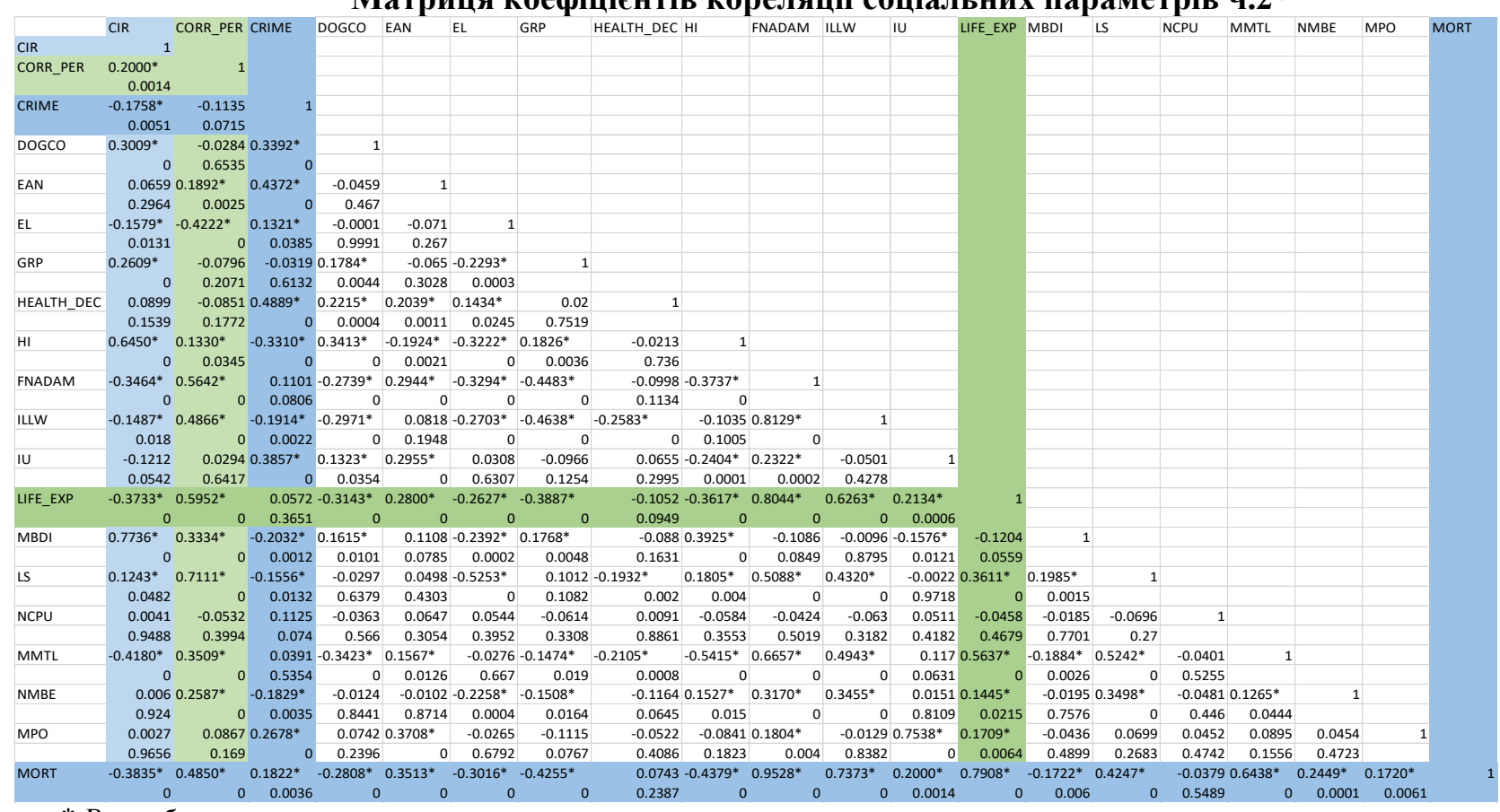

* Розроблено автором

Проаналізувавши коефіцієнти, наведені в МРО мають слабкий рівень зв'язку з вихідними таблиці 3, параметри DOGCO, IU, NCPU, NMBE, параметрами, тому їх треба виключити з аналізу.

Таблиця 4

Матриця коефіціснтів кореляції соціальних параметрів ч.3*

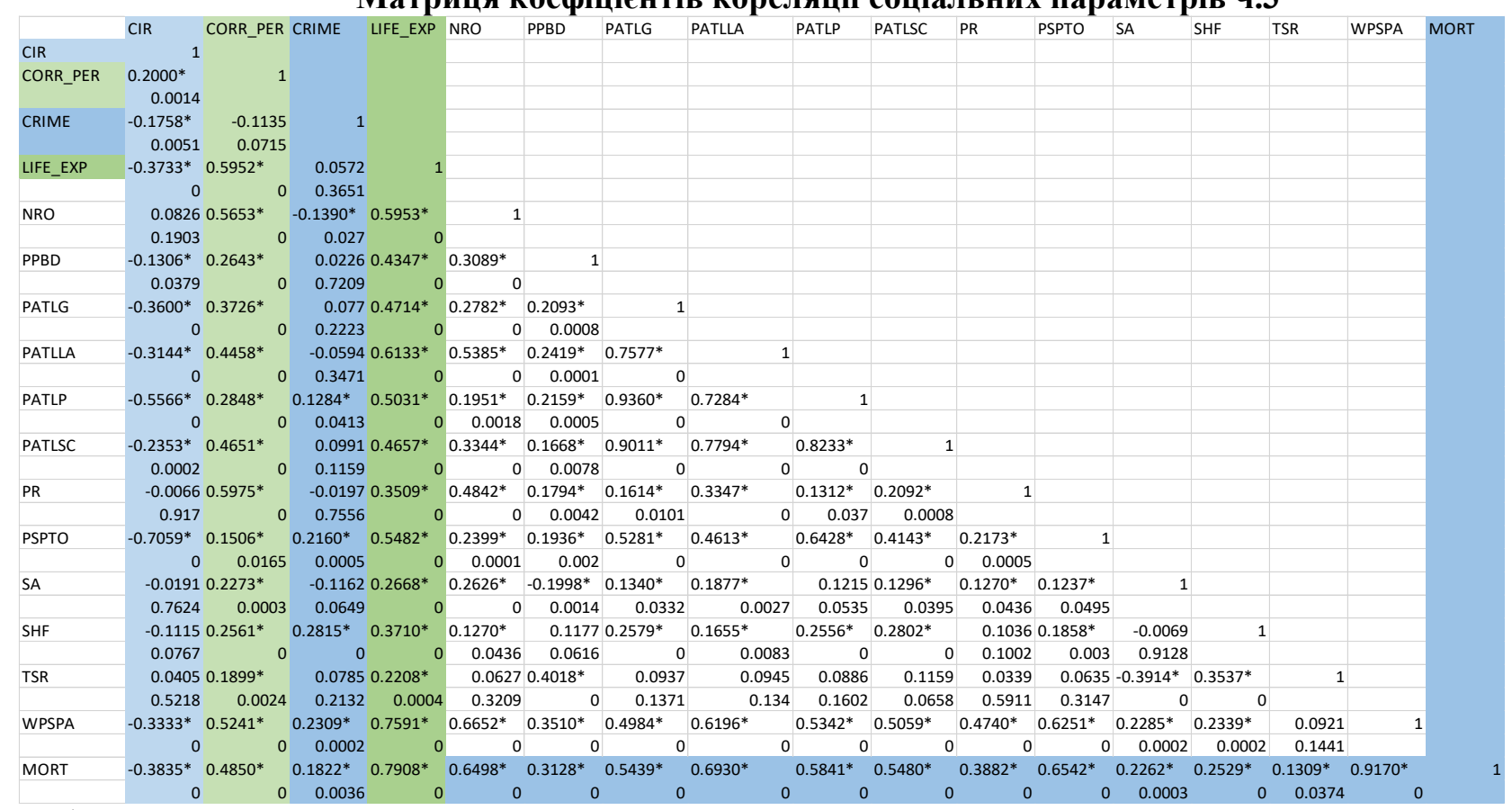

* Розроблено автором

Проаналізувавши коефіцієнти, наведені в інституцій, треба прибрати PATLG, PATLP, таблиці 4, параметри SA, SHF, TSR мають PATLSC. Рішення залишити лише «Рівень довіри слабкий рівень зв'язку з вихідними параметрами, до державних інституцій: Місцеві органи влади» тому їх треба виключити з аналізу.

Аби позбутися мультиколінеарності серед показників рівня довіри до державних (PATLLA) був зумовлений більшою репрезентативністю цього показника серед подібних. 
Дуже привертає увагу показник «Кількість зайнятого населення у сфері державного управління» (WPSPA) через сильну кореляцію 3 показниками смертності, очікуваної тривалості життя, «Кількість релігійних організацій» та рівня довіри до державних інституцій. Прийнято рішення залишити параметр WPSPA для подальшого аналізу через відсутність очевидної залежності з вищезазначеними параметрами.

Через вище згадані причини були прибрані 3 аналізу параметри: BN, DNTR, DOGCO, IU, NCPU, NMBE, MPO, SA, SHF, TSR, PATLG, PATLP, PATLSC.

\section{Аналіз екологічної сфери}

У цій сфері ми маємо вхідних та вихідних параметрів разом 33. Аналіз буде складатися 3 двох частин та за результатом будуть створені дві таблиці.

Спочатку планувалося використання 4 вихідних факторів. Але на початковому етапі дослідженні виявилося, що при використанні розрахованих параметрів «Забруднення довкілля (атмосферного повітря і поверхневих водних об'єктів)» (POL) та «Вплив на змінювання клімату» (показник щільності викидів двоокису карбону (CН) коефіцієнт кореляції між ними наближається до 1. Тому має сенс один 3 цих двох вихідних параметрів прибрати. Параметр POL був розрахований як сума різних видів відходів поділена на параметр «Площу адміністративно-територіального утворення» (ACC1), тому він, як наслідок, має стійку силу лінійного зв'язку 3 усіма параметрами, пов'язаними 3 відходами. Через це було прийняте рішення виключити його з аналізу.

Іншим результатом цього попереднього аналізу став вплив додаткової варіації від параметра «Площа адміністративнотериторіального утворення» (АCC1) через який більше половини вхідних параметрів не залишаються для подальшого аналізу внаслідок низького показника кореляції 3 вихідними параметрами. Цей вплив спричинено розрахунком параметрів POL та $\mathrm{CCH}$. А саме параметр POL був розрахований як сума різних видів відходів поділена на параметр АCC1. Так само параметр $\mathrm{CCH}$ був розрахований як параметр CCH1 на АCC1. Тому прийнято рішення використовувати ССН1 замість $\mathrm{CCH}$.

Урахувавши всі вище наведені умови та провівши кореляційний аналіз, результатом стало заперечення тези про негативний вплив ACC1. При виключенні цього впливу залишається 3 вхідних параметри та зникає можливість створити більш-менш об'єктивну модель. Тому буде більш раціонально включити вплив ACC1, який підвищує кількість параметрів в моделі майже вдвічі. Тобто рішення про використання $\mathrm{CCH} 1$ замість $\mathrm{CCH}$ наразі скасовано.

Таблиця 5

Матриця коефіціснтів кореляції екологічних параметрів ч.1*

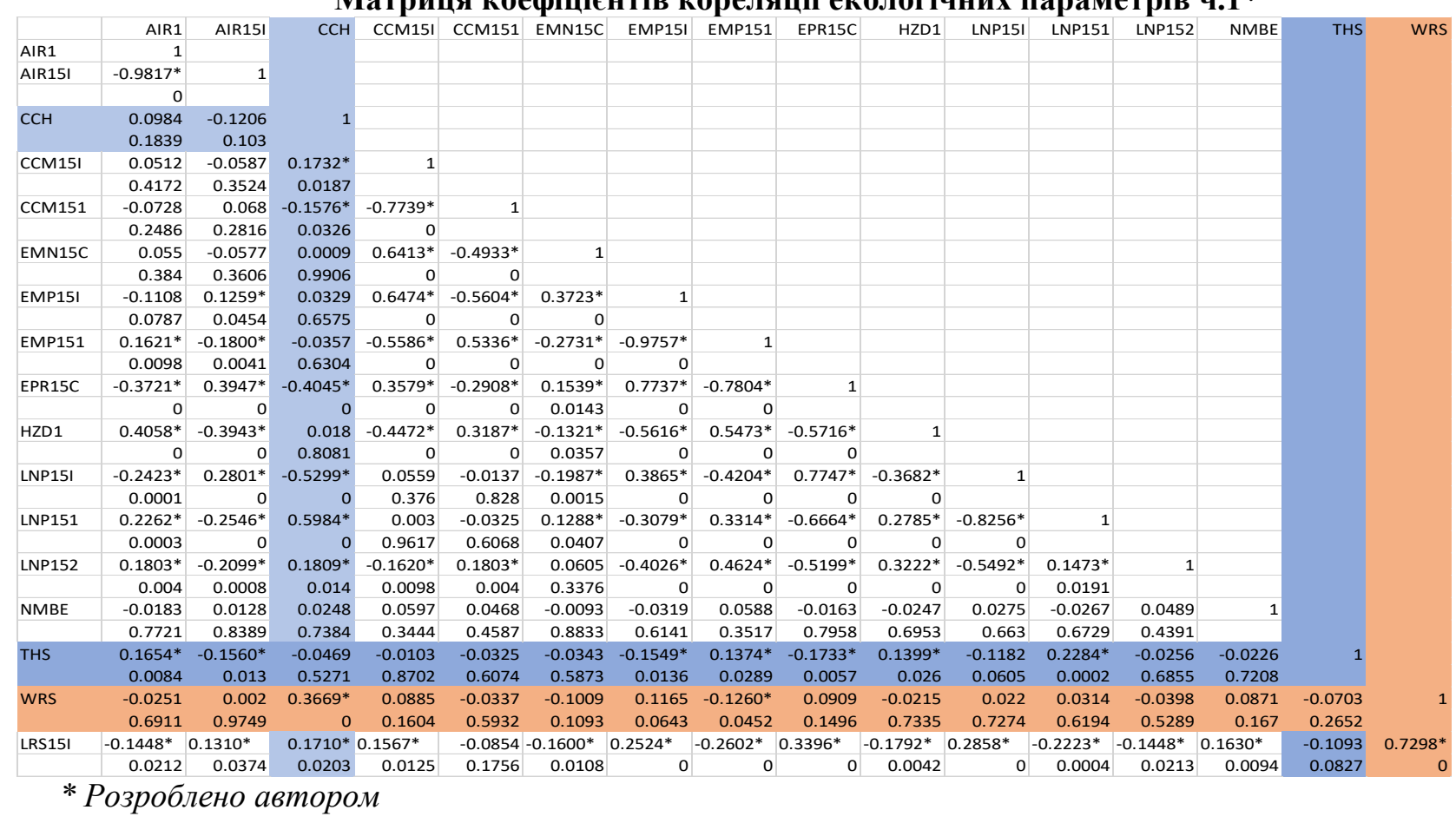

Проаналізувавши коефіцієнти, наведені в таблиці 5, всі параметри за винятком EPR15C, LNP151, LNP151 та LRS151 мають слабкий рівень зв'язку з вихідними параметрами, тому їх треба виключити 3 аналізу. Також параметр 
LNP151 треба прибрати через мультиколініарність.

Таблиця 6

Матриця коефіціснтів кореляції екологічних параметрів ч.2*

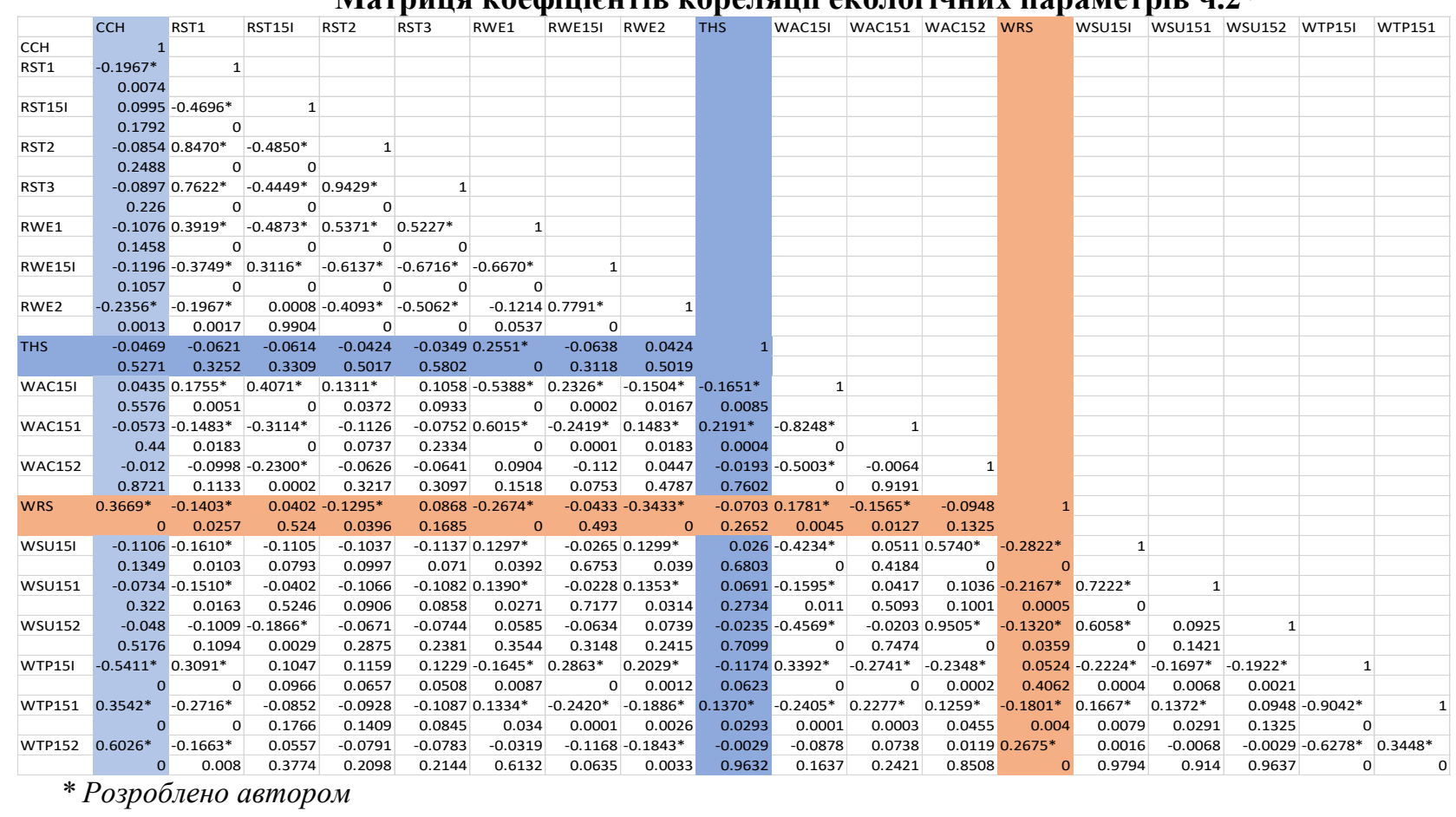

Проаналізувавши коефіцієнти, наведені в таблиці 6, всі параметри за винятком WTP151 та WTP152 мають слабкий рівень зв'язку 3 вихідними параметрами, тому їх треба виключити з аналізу. Також треба врахувати, що WTP151 включає в себе WTP151 та WTP152, що означає виключити з аналізу також WTP15l.

Також загроза «Техногенна небезпека» (описана за допомогою збитків від техногенних надзвичайних ситуацій в регіонах параметра THS) мала дуже слабкі зв'язки з усіма вхідними параметрами. Тому цю загрозу також виключили зі списку вихідних параметрів.

Висновки i перспективи подальших досліджень. За результатами дослідження взаємозв'язків між вхідними та вихідними індикаторами сталого розвитку на основі кореляційного аналізу сформовано систему параметрів сталого розвитку:

1. Економічну систему представлено 13 вхідними ("Економічно активне населення", "Частка витрат на продукти харчування та безалкогольні напої у середньому за місяць у розрахунку на одне домогосподарство", "Кількість активних підприємств", "Капітальні інвестиції", "Обсяги імпорту товарів і послуг", "Обсяг наукових та науково-технічних робіт, виконаних власними силами наукових організацій", "Обсяги обороту роздрібної торгівлі", "Обсяг реалізованої інноваційної продукції", "Обсяг реалізованих послуг", "Обсяг реалізованої промислової продукції (товарів, послуг)", "Обсяг витрат за напрямами інноваційної діяльності", "Потреба підприємств у працівниках", "Продукція сільського господарства") та 4 вихідними параметрами ("Технологічна відсталість", "Наявний доход у розрахунку на одну особу", "Ступінь зносу основних засобів", "Безробітне населення").

2. Соціальну систему представлено 25 вхідними ("Рівень забезпеченості житлом", "Чисельність ВІЛ-інфікованих", "Рівень довіри до громадських організацій", "Загальна кількість осіб, які потерпіли від злочинів", "Охоплення дітей дошкільними навчальними закладами за регіонами", "Наявність персональних комп'ютерів у домогосподарствах", "Рівень свободи від корупції (Індекс сприйняття корупції)", "Довіра до церкви", "Розподіл газет за типами та регіонами", "Економічно активне населення", "Індикатор рівня освіти", "Смертність населення за причинами смерті", "Індикатор стану та охорони здоров'я людей", "Частка витрат на продукти харчування та безалкогольні напої у середньому за місяць у розрахунку на одне домогосподарство", "Валовий регіональний продукт у розрахунку на одну особу", "Частка населення із середньодушовими еквівалентними грошовими доходами на місяць нижче прожиткового мінімуму", "Задоволеність життям", "Нерівність розподілу матеріальних благ", "Рівень довіри до 
ЗМІ", "Кількість релігійних організацій", "Рівень довіри до державних інституцій: Місцеві органи влади", "Забезпеченість населення лікарями всіх спеціальностей", "Готовність до протестів", "Забезпеченість населення об'єктами фізичної культури та спорту", "Кількість зайнятого населення у сфері державного управління") та 5 вихідними параметрами ("Соціальна нерівність", "Корупція", "Злочинність", "Зниження тривалості життя", "Погіршення здоров'я").

3. Екологічну систему представлено 4 вхідними ("Екологічне навантаження i небезпеки", "Утворення відходів I-III класи небезпеки у розрахунку на квадратний кілометр території", "Земельні ресурси", "Скидання забруднених зворотних вод у поверхневі водні об'єкти") та 2 вихідними параметрами ("Вплив на змінювання клімату", "Дефіцит водних ресурсів").

\section{ПЕРЕЛІК ВИКОРИСТАНИХ ДЖЕРЕЛ}

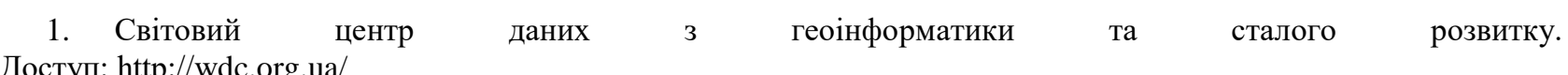
Доступ: http://wdc.org.ua/

2. Аналіз сталого розвитку: глобальний і регіональний контексти. Частина 2. Україна в індикаторах сталого розвитку 2013 / Міжнародна Рада з науки (ICSU), Комітет із системного аналізу при Президії НАН України, Світовий Центр даних з геоінформатики та сталого розвитку, Інститут прикладного системного аналізу НАН України і МОН України. - К. : НТУУ "КПІ", 2014. - 172 с.. - ISBN 978-966-622-644-3

3. Babets I.H. Problems of methodology research for sustainable development of region in the context of economic security/ Babets I.H., Sergienko S.V. // Economic Bulletin University. - 2014 - Vol. 22 (1). - S. 121-127

4. Кривенко Л.В. Соціально-економічні інструменти забезпечення сталого розвитку / Л.В. Кривенко // Механізм регулювання еко- номіки. - 2011. - № 2. - С. 33-37.

5. Андрушків, Б. М. Інноваційні засоби формування концепції оцінювання сталого розвитку у системі: підприємство - галузь - регіон - держава (євроінтеграційні аспекти) [Текст] / Б. М. Андрушків, Л. М. Мельник, О. Б. Погайдак // Український журнал прикладної економіки. - 2016. - Том 1. - № 2. - С. 6-17. - ISSN 24158453.

6. Мельник Л.Г. Экономика развития : монография / Л. Г. Мельник. - Сумы : Университетская книга, 2006. -662 c.

7. Войтко С. В. Динаміка соціально-економічних індексів у вимірах сталого розвитку // Збірник наукових праць "Публічне управління та адміністрування". Випуск 1. 2015. с. 42-51

8. Трофимова В. В. Концепція сталого розвитку як основа постіндустріальних моделей розвитку / В. В. Трохимова // Інвестиції - практика та досвід. - 2010. - № 8. - С. 33-37.

9. «National Statistician's article: measuring regional economic performance»K Dunnell - Economic \& Labour Market Review, 2009

10. «Understanding power and rules of thumb for determining sample sizes» CRW VanVoorhis, BL Morgan Tutorials in Quantitative Methods for Psychology, 2007. Доступ: http://www.tqmp.org/Content/vol03-2/p043/p043.pdf

\section{REFERENCES}

1. World Data Center for Geoinformatics and Sustainable Development.

Access: http://wdc.org.ua/

2. Zgurovsky, M.; Yefremov, K. (2013), Sustainable Development Analysis: Global and Regional Contexts. P.2. Ukraine in indicators of Sustainable Development, Politechnika, Kyiv

3. Babets I.H. Problems of methodology research for sustainable development of region in the context of economic security/ Babets I.H., Sergienko S.V. // Economic Bulletin University. - 2014 - Vol. 22 (1). - S. 121-127

4. Krivenko, L. V. (2011), "Socialyno-ekonomichni instrumenty zabezpechenya staloho rozvitku”, Mechanism of regulation of the economy. [in Ukrainian]

5. Andrushkiv, B. M.; Melnik, L. M.; Pohaydak, O. B. (2016), "Innovatsiini zasoby formuvannia kontseptsii otsiniuvannia staloho rozvytku u systemi: pidpryiemstvo - haluz - rehion - derzhava (yevrointehratsiini aspekty)", Ukrainian Journal of Applied Economics. [in Ukrainian]

6. Melnyk, L. G. (2006) "Ekonomika razvitiya : monografiya”, Sumy: University Book. [in Russian] 
7. Voitko S. V. (2015), "Dynamika sotsialno-ekonomichnykh indeksiv u vymirakh staloho rozvytku/l Zbirnyk naukovykh prats "Publichne upravlinnia ta administruvannia". Vypusk 1". Kiev. [in Ukrainian]

8. Trofimova, V. V. (2010), "Kontseptsiia staloho rozvytku yak osnova postindustrialnykh modelei rozvytku", Investing - Practice and Experience. [in Ukrainian]

9. Dunnell K. (2009), «National Statistician's article: measuring regional economic performance» - Economic \& Labour Market Review

10. VanVoorhis CRW, Morgan BL (2007), «Understanding power and rules of thumb for determining sample sizes» - Tutorials in Quantitative Methods for Psychology

Одержано 14.09.2017 p. 